\title{
Business Performance of Vandana Self Help Group (SHG): A Case Study of Koriya District of Chhattisgarh
}

\author{
Shweta Singh ${ }^{*}$ and A. K. Gouraha \\ Department of Agricultural Economics, Agricultural Economics, Indira Gandhi Krishi \\ Vishwavidyalaya, Raipur, C.G., India \\ *Corresponding author
}

\section{A B S T R A C T}

\section{Keywords}

Net income,

Benefit-cost ratio,

Total cost

Article Info

Accepted:

12 October 2020

Available Online:

10 November 2020
The present study was focused to investigate the "business performance of vandana Self Help Group (SHG): a case study of Koriya district of Chhattisgarh state of India".Vandana self-help group was purposely selected for the present study which is situated in the Koriya district of Chhattisgarh state. Vandana self-help group produces vermicompost and they were using a constructed method for vermicompost production. Primary data was collected from the Vandana self-help group by a personal interview with the help of interview schedules. The primary data were classified and tabulated in the light of given objectives and analyzed as per the appropriate economics tools. This study revealed that per bed production of vermicompost was $40 \mathrm{qt}$. because in the constructed method vermicompost is produced in 4 cycles. Net income on the total cost was Rs.15816. The benefit-cost ratio of per bed was (1:0.6). The total cost of vermicompost production per bed was Rs.24184. The total production of vermicompost by Vandana SHG was 3680qt. because of 92 beds in their constructed unit. Net income on the total cost was Rs.1455072. The benefit-cost ratio was (1.0.6). The Total cost of vermicompost production for 92 beds per year was Rs.2224928 in the constructed method.

\section{Introduction}

Self Help Group (SHG) is a small association of people, ideal from the same socioeconomic background. Its approach is a new pattern in the field of rural developments whose main objective is to raise the wellbeing of the people and to develop collective decision-making among members \&motivate members to taking part in social duties particularly related to development. It is initiated as a self-employment program.
Self Help group is a village-based financial mediator community of not more than 10-20 people. It helps people who do not have access to form financial structure. SHGs works as an assembly to provide support and space.

The study attempt to understand business performance, in turn, helps to review the market sustainability of the women SHGs and enhancing the business performance with suitable Marketing Strategies for profitability 
that may be important to make the organization and effective institution arrangement of the women leading to the development of rural India.

Vandana self-help group was selected to fulfill the objective-

To work out the business performance of Vandana self- help group.

\section{Materials and Methods}

The Koriya district was purposively selected for the present study, from where the primary data were collected by interviewing the members of "Vandana SHGs" for the present investigation. Primary data were collected from the Vandana SHGs through a personal interview with the help of pre-tested wellprepared interview schedules covering various aspects to answer the objectives of this study. The primary data recorded regarding farm assets, fixed and variable cost of vermicompost production, operation wise labor utilization, total quantity sold, price of vermicompost, agency to whom sold, place of sell, and expenditure incurred during the marketing of produce, etc.

\section{Analysis of data}

Cost of cultivation $=$ Total Fixed cost + Total Variable cost

Gross Income $=$ Physical Production $\times$ Price/qt.

Net Income $=$ Gross Income - Total Cost

Input-Output Ratio = Gross Income $/$ Total Cost

Benefit - Cost Ratio $=$ Net Income $/$ Total Cost

\section{Results and Discussion}

Item wise expenditure of vermicompost production for the constructed method was calculated and is presented in Table 1. The variable cost is the cost that changes as the quantity of the goods or services that a business produces changes. The total variable cost of Vandana self- help group is Rs.728 for 1 quintal and Rs.5746 for 1 bed in one period.

The total fixed cost includes the expenses that do not change as a function of the activity of a business, within the relevant period of time. The fixed cost of the Vandana self-help group is Rs.30 for 1 quintal and Rs.300 for 1 bed in one period.

The gross income is the amount that a business earns from the sale of goods or services, before selling, administrative tax, and other expenses have been deducted. The gross income is Rs.1000 for 1 quintal and Rs.10000 for 1 bed. The input-output ratio of Vandana self-help group is 1:1.6 for 1 quintal and 1:1.6 for 1 bed.

The net income is the amount remaining after subtracting all costs and expenses from revenue. The net income of the Vandana selfhelp group is Rs.242 for 1 quintal and Rs.3954 for 1 bed in one period. The net costbenefit Ratio for 1 quintal is 1:0.6 and for 1 bed is 1:0.6 (Fig. 1).

\section{Output and returns}

Total Cost, production, gross income, and net income was calculated in table 2. It was observed that the production of vermicompost in a year of 1 bed was 40q and for 92 beds yearly production was observed $3680 \mathrm{q}$ in the constructed method. 
Table.1 Business performance of Vandana Self-help group

\begin{tabular}{|c|c|c|c|}
\hline Particulars & Unit(Rs./q) & $\begin{array}{l}\text { Physical unit per } \\
\text { bed material(q) }\end{array}$ & $\begin{array}{c}\text { Cost of } 1 \text { bed }(\text { Rs. }) \\
\text { Size of bed }(10 \times 4 \times 2 \text { feet })\end{array}$ \\
\hline \multicolumn{4}{|l|}{ Variable cost } \\
\hline Cow Dung @ Rs.0.88 & 88 & 9 & 792 \\
\hline Crop Wastage @ Rs.1.26 & 126.5 & 6 & 759.96 \\
\hline Electricity \& Water Charges & 2 & 10 & 20 \\
\hline Earthworm cost @ Rs.157/kg & $157 / \mathrm{kg}$ & $4 \mathrm{~kg}$ & 628 \\
\hline Labor charges & 225 & 10 & 2250 \\
\hline Marketing \& packaging cost & 105 & 10 & 1050 \\
\hline Miscellaneous Cost & 25 & 10 & 250 \\
\hline Total Variable Cost(A) & 728 & & 5746 \\
\hline \multicolumn{4}{|l|}{ Fixed Cost } \\
\hline $\begin{array}{l}\text { The rental value of the constructed } \\
\text { unit for } 3 \text { months } 300\end{array}$ & 30 & 10 & 300 \\
\hline Total Fixed Cost (B) & 30 & 10 & 300 \\
\hline Total Cost $(A+B)$ & 758 & & 6046 \\
\hline Gross Income & 1000 & & 10000 \\
\hline Input-Output Ratio & $1: 1.6$ & & $1: 1.6$ \\
\hline Net Income & 242 & & 3954 \\
\hline C:B Ratio & $1: 0.6$ & & $1: 0.6$ \\
\hline
\end{tabular}

Table.2 Production, total cost, gross income and net income for the constructed method of vermicompost production. (Rs./Year)

\begin{tabular}{|c|c|c|c|}
\hline S.no. & Particulars & $\begin{array}{l}\text { Cost and production of } 1 \\
\text { bed. (In whole year } 4 \\
\text { times) } \\
\text { Size of bed }(40 \times 4 \times 2 \text { feet) }\end{array}$ & $\begin{array}{l}\text { Cost and production of } \\
92 \text { beds. }\end{array}$ \\
\hline 1 & Total cost & 24184 & 2224928 \\
\hline 2 & Production & 40 & 3680 \\
\hline 3 & Gross income & 40000 & 3680000 \\
\hline 4 & Input-Output Ratio & $1: 1.6$ & $1: 1.6$ \\
\hline 5 & Net income & 15816 & 1455072 \\
\hline 6 & C: B Ratio & 1:0.6 & 1:0.6 \\
\hline
\end{tabular}


Fig.1 Total cost and net income of constructed method of vermicompost production per quintal and bed

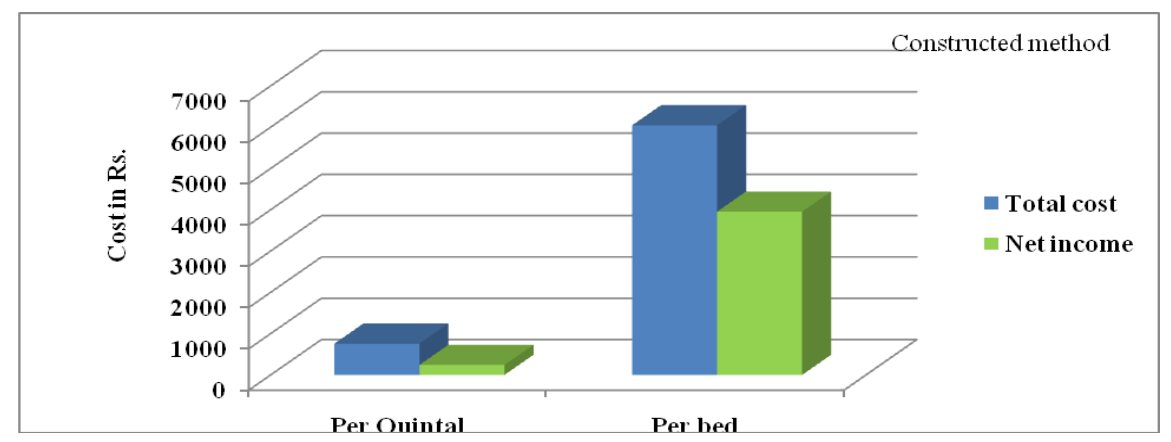

The total cost of vermicompost production was calculated in the constructed method was Rs. 24184 for 1 bed and it was calculated that the yearly total cost for 92 beds was Rs.2224928.

Total gross return earned by Vandana selfhelp group was Rs.40000 from 1 bed and yearly total gross return from 92 beds by Vandana SHG was Rs.3680000 in the constructed method.

Net income on the total cost for 1 bed was Rs.15816 and yearly net income for 92 beds was Rs.1455072 in the constructed method.

In conclusion it was calculated that the total cost of vermicompost by Vandana SHG was Rs.758/qt. Rs. 24184 per bed and Rs. 2224928 for 92 beds for the production of vermicompost in the constructed method. The net income of vermicompost production was Rs.3954/qt. Rs.15816 per bed and Rs.1455072 per year on total cost in constructed method. The benefit-cost ratio was $(1: 0.6)$ in the constructed method. It is concluded that vermicompost distribution through the producer to retailer to consumer channel is more used by the Vandana selfhelp group than other channels of distribution. Attack of ants to the vermicompost, low price for vermicompost, lack of market information was some of the major constraints faced by the Vandana self-help group.

\section{References}

Amita Rani and Pawan Kumar Dhiman. Dimensions And Apprehensions of Self-Help Groups-An Analysis. International Journal of Economics and Business modeling. 3.2 (2012):172-176 Chauhan HK, Singh K (2015) Potency of Vermiwash with Neem plant parts on the Infestation of Eariasvittella (Fabricius) and Productivity of Okra (Abelmoschus esculentus) (L.) Moench. Asian J Res Pharm Sci 5(1):36-40.

Chatterjee, S., and Apartment, M. (2014). Self-help groups and economic empowerment of rural women: A case study. International Journal of Education and Management Studies, 4(2), 103.

Das. R., NARMAN. R.N. and BARUAH. P.K. 2001. Performance of Self-Help Groups in Sonitpur District of Assam. India Journal of Agricultural Economics. 56(3), 466.

Domínguez JJ, Edwards CA (2011) Biology and ecology of earthworms species used for vermicomposting. In: Edwards CA, Arancon NQ, Sherman RL (eds) Vermiculture technology: earthworms, organic waste and environmental management. CRC Press, Boca Raton, pp 27-40

Ganapathi, R., and S. Anbu Malar. "Customer satisfaction of MEPZ- special 
economic zone.” Asia-Pacific Business Review, vol. 4, no.1, 2008

Gandhi, M., Sangwan, V., Kapoor, K.K. and Dilbaghi, N. (1997) Composting of household wastes with and without earthworms. Environment and Ecology, $15,432-434$

Padal , S.R.(2011) Effect of Self Help Groups in economic empowerment of rural women in Andhrapradesh. Journal of Research in Peace, Gender and Development 2011 Vol.1 No.3 pp.101110 ref. 10

Ramanujam, V. and Homiga, U. (2014). A study on the performance of Self Help
Groups in Mysore District, International Journal of Business and Administration

Reddy BV, Honnaiah C, Reddy PNS, Kale RD, Balakrishna AN (2009). "Economics of vermicompost production and marketing in Southern Karnataka", Mysore J. Agric. Sci., Vol. 43, No. 1, pp. 125-131.

Shivakumara C (2008). "Production and marketing of vermicompost in Karnataka: A case of Dharwad district", unpublished M.Sc. Thesis. University of Agricultural Sciences, Dharwad, Karnataka, India.

\section{How to cite this article:}

Shweta Singh and Gouraha, A. K. 2020. Business Performance of Vandana Self Help Group (SHG): A Case Study of Koriya District of Chhattisgarh. Int.J.Curr.Microbiol.App.Sci. 9(11): 1595-1599. doi: https://doi.org/10.20546/ijcmas.2020.911.189 